\title{
ИНСТИТУЦИОНАЛЬНАЯ СТРУКТУРА СИСТЕМЫ ФИНАНСОВЫХ ИНСТИТУТОВ РЕГИОНА *
}

\section{(C) 2018 Коновалова Мария Евгеньевна}

доктор экономических наук, заведующая кафедрой экономической теории

Самарский государственный экономический университет

443090, Самара, ул. Советской Армии, 141

E-mail:mkonoval@mail.ru

(c) 2018 Кузьмина Ольга Юрьевна

кандидат экономических наук, доцент кафедры экономической теории

Самарский государственный экономический университет

443090, Самара, ул. Советской Армии, 141

E-mail: pisakina83@yandex.ru

(c) 2018 Недорезова Елена Сергеевна

кандидат экономических наук, доцент кафедры экономической теории

Самарский государственный экономический университет

443090, Самара, ул. Советской Армии, 141

E-mail: nedlen@yandex.ru

В статье проведено теоретические исследование системы финансовых институтов региона и ее институциональной структуры. Классифицированы подходы, раскрывающие содержание категории «финансовый институт». Обосновано, что применение подхода «финансовые институты-финансовые отношения» позволяет проанализировать взаимодействия субъектов в процессе воспроизводства отношений. Использование этого подхода позволило сформулировать авторское определение системы финансовых институтов региона и выделить элементы ее институциональной структуры.

Ключевые слова: финансовый институт, финансовые отношения, система финансовых институтов региона, институциональная структура.

Прежде чем раскрывать содержание категории «система финансовых институтов региона», необходимо определиться с природой понятия «финансовый институт».

В настоящее время в социально-экономической литературе существуют различные трактовки категории «финансовый институт» (см. табл.).

В современной отечественной и зарубежной литературе самым распространённым является подход, при котором финансовые институты рассматриваются как финансовые посредники.

Существуют различные определения финансовых посредников. Так, Колб и Родригес считают, что финансовые посредники представляют собой финансовые институты, которые аккумулируют фонды от одной группы инвесторов и делают их доступными для других экономических единиц. Финансовые посредники могут быть представлены различными организациями, ко- торые выпускают финансовые обязательства и продают их в качестве активов за деньги [1].

Ф.М-Г. Топсахалова отмечает, что согласно положениям теории финансового посредничества основным собственником инвестиционных ресурсов является население, а основным потребителем - предприятия и организации.

Экономике развитых стран присуща сложная и многообразная структура институтов, осуществляющих мобилизацию инвестиционных ресурсов с последующим их вложением в предпринимательскую деятельность. Эти финансовые институты, выступая финансовыми посредниками, аккумулируют отдельные сбережения домашних хозяйств и фирм в значительные массы инвестиционного капитала, который затем размещается среди потребителей инвестиций [2].

Таким образом, подход «финансовые институты - финансовые посредники», связан с

\footnotetext{
* Исследование выполнено при финансовой поддержке РФФИ и Правительства Самарской области в рамках научного проекта № 18-410-630003
} 


\section{Таблица. Трактовки категории «финансовый институт»}

\begin{tabular}{|c|c|}
\hline $\begin{array}{l}\text { Финансовый институт - совокупность различных кредитно-финансовых } \\
\text { организаций, целью которых является обеспечение экономических субъек- } \\
\text { тов различных уровней денежными средствами на возмездной основе. }\end{array}$ & $\begin{array}{l}\text { Представители классического- } \\
\text { институционализма (Веблен, } \\
\text { Д. Коммонс, У.К. Митчелл) }\end{array}$ \\
\hline $\begin{array}{l}\text { Кредитно-финансовый институт - совокупность правил, регламентирую- } \\
\text { щих поведение экономических субъектов и упорядочивающих взаимодей- } \\
\text { ствие между ними в сфере кредитно-финансовых отношений, и механиз- } \\
\text { мов, обеспечивающих соблюдение данных правил }\end{array}$ & $\begin{array}{l}\text { Неоинституционалисты } \\
\text { (Дж. Гэлбрейт, Ф. Перру, } \\
\text { Р. Хейлбронер, Г. Мюрдаль) }\end{array}$ \\
\hline $\begin{array}{l}\text { Финансовый институт трактуется как финансовый посредник между креди- } \\
\text { торами и заемщиками или между инвесторами и сберегательными учреж-- } \\
\text { дениями, действующими на договорной основе }\end{array}$ & Романова Т.Ф., Иванова О.Б \\
\hline $\begin{array}{l}\text { Финансовые институты - это посредники, обеспечивающие встречу заем- } \\
\text { щика и инвестора (кредитора) на финансовом рынке }\end{array}$ & Иванов В.М. \\
\hline $\begin{array}{l}\text { Финансовые институты - обеспечивают своих участников необходимой } \\
\text { для их нормальной ориентации в рыночном пространстве, специальную } \\
\text { информацию, но прежде всего, способствуют созданию условии обеспечи- } \\
\text { вающих совместимость субъектов в их финансовых действиях }\end{array}$ & Беков Р.С. \\
\hline $\begin{array}{l}\text { Финансово-кредитные институты - государственные и частные, коммер- } \\
\text { ческие организации, уполномоченные осуществлять финансовые операции } \\
\text { по кредитованию, депонированию вкладов, ведению расчетных счетов, } \\
\text { купле и продаже валюты и ценных бумаг, оказанию финансовых услуг и др. }\end{array}$ & Борисов А.Б. \\
\hline $\begin{array}{l}\text { Финансовый институт - учреждение, которое выпускает депозиты и про- } \\
\text { чие финансовые обязательства и направляет средства на предоставление } \\
\text { ссуд и приобретение других финансовых активов. Финансовые институты, } \\
\text { представляют собой организации, выпускающие финансовые обязательства } \\
\text { (т.е. требования к себе) и продающие их в качестве активов за деньги }\end{array}$ & Грязнова А.Г. \\
\hline $\begin{array}{l}\text { Кредитно-финансовый институт - кредитно-финансовые организации, где } \\
\text { правила и нормы их функционирования, а также } \\
\text { механизмы, обеспечивают соблюдение этих правил и норм, в условиях мас- } \\
\text { сового применения информационных и телекоммуникационных техноло- } \\
\text { гий, перевода и хранения финансовой информации, является финансовым } \\
\text { посредником между кредиторами и заемщиками }\end{array}$ & Карташов К.А. \\
\hline
\end{tabular}

Источник. Литвинцева, Г.А. Словарь терминов поинституциональной экономике. Москва.,2016. С. 267; Романова Т.Ф., Иванова О.Б. Финансы: учеб. пособие. Ростов н/Д. 2015. С. 48; Иванов В.М. Финансовый рынок. Конспект лекции. 2-е изд. Киев. КОО, 2014. С. 6; Беков Р.С. Научные труды ДонНТУ. Серия: экономическая. Выпуск 89-3. 2015. С. 34; Борисов, А.Б. Большой экономический словарь. Москва. 2014. С. 345; Словарь терминов, понятий и определений по экономике, финансам и бизнесу [Электронный ресурс]. Режим доступа: http://termin.bposd.ru/publ/22-1-0-19950; Финансово-кредитный энциклопедический словарь / Кол.авторов; Под общ. ред. А.Г. Грязновой. Москва. 2016.С. 278; Карташов, К.А. Финансовые институты в инфраструктуре кредитных отношений, их роль и особенности функционирования (опыт Великобритании) // Вестник Краснодарского Университета МВД России. № 3. 2017. С. 91-97.

узким пониманием финансовых институтов по организационному (институциональному) наполнению, то есть по совокупности различных кредитно-финансовых организаций. В таком варианте проявляется институциональный метод, подразумевающий анализ структуры элементов, их организацию без выстраивания взаимосвязей и взаимозависимостей между ними.

Однако на наш взгляд этот подход не в полной мере описывает функционирование финансовых институтов в современных условиях.

По нашему мнению институт представляет форму организации хозяйственной деятельности, организующую и закрепляющую способы взаимодействия субъектов в процессе воспроизводства отношений. То есть институт способствует формированию и развитию отношений между институциональными субъектами, явля- ется основой этих отношений, в этом проявляется системный подход исследования институтов и их взаимосвязи, соподчинениях.

Опираясь на эти рассуждения, мы определяем трактовку финансового института, сформулированную Востриковым Г.Г. как наиболее правильную и схожую с нашим пониманием категории финансовый институт. По его мнению, финансовый институт - группа однородных экономических отношений, взаимосвязанных по формам и методам аккумуляции или распределения денежных средств. [3]

Дополняя это определение, можно сказать, что финансовый институт - это основопологающий элемент системы экономических институтов, который представляет собой форму организации финансовой деятельности, закрепляющую способы взаимодействия субъектов в 
процессе воспроизводства отношений по поводу аккумуляции, распределения и использования денежных средств в соответствии с принятыми правилами, регламентирующими поведение этих субъектов и упорядочивающими взаимодействие между ними в сфере финансовых отношений, и механизмами, обеспечивающими соблюдение данных правил.

Определившись с содержанием категории «финансовый институт» перейдем к категории «система финансовых институтов региона».

На наш взгляд принципиально важным является вопрос соотнесения двух понятий: финансовая система и система финансовых институтов. Для того чтобы определить как они между собой связаны, необходимо выбрать какому подходу придерживаться при рассмотрении сущности категории «финансовый институт».

Ранее в работе отмечалось, что такие экономисты как Романова Т.Ф., Иванова О. Б, Иванов В.М., Топсахалова Ф.М.-Г. и др. считают, что финансовые институты - это финансовые посредники. Этот подход определяет финансовую система как систему финансовых посредников, которые обеспечивают перераспределение и эффективное использование свободных финансовых ресурсов в экономике.

По определению Всемирного банка, финансовая система представляет собой систему финансовых посредников, которые обеспечивают перераспределение и эффективное использование свободных финансовых ресурсов в экономике на основе использования широкого спектра финансовых инструментов и разнообразных рынков. [4]

На наш взгляд, механизм финансового посредничества реализуется через финансовый сектор. Финансовый сектор или сектор финансовых корпораций - все корпорации-резиденты, включая квазикорпорации, основной функцией которых является предоставление финансовых услуг, включая страхование и пенсионное обеспечение, другим институциональным единицам. [5]

Финансовый сектор отличается от нефинансового сектора в связи с тем, что финансовые корпорации заняты, преимущественно, предоставлением финансовых услуг, включая финансовое посредничество, которые в значительной степени отличаются от других типов производственной деятельности.

Финансовое посредничество может быть определено как вид деятельности, в процессе которой институциональная единица аккумулирует финансовые ресурсы путем принятия финансовых обязательств за собственный счет с целью направления привлеченных средств другим институциональным единицам путем кредитования или приобретения финансовых активов иным способом.

Отличительными особенностями финансового посредничества являются:

- формирование финансовых обязательств для последующего кредитования;

- трансформация финансовых инструментов по срочности, процентной ставке, валюте, номиналу и другим характеристикам;

- принятие на себя финансовых рисков.

С точки зрения Школьник И.Ю., финансовый сектор представлен системой финансовых посредников в форме деятельности банков и небанковских финансовых учреждений во взаимосвязи с субъектами реального сектора экономики по поводу перераспределения временно свободных финансовых ресурсов, обеспечивает нужды институциональных секторов экономики в формировании государственных финансов, финансов предприятий и финансов домохозяйств.

В связи со всеми рассуждениями, мы считаем, что в данном случае категории «финансовая система» и «финансовый сектор» следует отождествлять, что является узким подходом определения финансовой системы.

По нашему мнению финансовый сектор является одной из важнейших сфер национальной экономики, где происходит формирование и распределение финансовых ресурсов и услуг, связанных с деятельностью финансовых учреждений.

Структура финансового сектора имеет свои особенности.

Финансовый сектор включает преимущественно банки. По мнению Науменковой С. С. и Мищенко А.П., это обусловлено следующим: информация о банковском секторе более доступна; он является основным объектом для осуществления текущего исследования и наблюдения за ходом реализации соответствующих мер финансовой политики; в странах с недостаточно развитыми финансовыми рынками на него приходится основная доля совокупных финансовых активов; решающая роль в осуществлении финансового посредничества в странах с неразви- 
тыми финансовыми рынками принадлежит неорганизованному финансовому рынку.

Такого подхода придерживается и Зимовец В.Г., который рассматривает финансовый сектор как консолидированные активы и обязательства банковской системы и НБУ.

В финансовый сектор по классификации МВФ входят:

- депозитные корпорации: центральный банк, прочие депозитные корпорации (банки), фонды денежного рынка,

- прочие финансовые корпорации: инвестиционные фонды (кроме фондов денежного рынка), прочие финансовые посредники (кроме страховщиков и пенсионных фондов), вспомогательные финансовые институты, кэптивные финансовые институты и кредиторы, страховые компании, пенсионные фонды.

В России в финансовый сектор входят институциональные единицы, являющиеся поднадзорными организациями мегарегулятору в лице Банка России:

- кредитные организации:

- банковские кредитные организации: банки с универсальной лицензией; банки с базовой лицензией;

- небанковские кредитные организации;

- некредитные финансовые организации: профессиональные участники рынка ценных бумаг; управляющие компаний инвестиционного фонда, паевого инвестиционного фонда и негосударственного пенсионного фонда; специализированные депозитарии инвестиционного фонда, паевого инвестиционного фонда и негосударственного пенсионного фонда; акционерные инвестиционные фонды; клиринговые организации; центральные контрагенты; организаторы торговли; центральный депозитарий; репозитарий; страховые компании; негосударственные пенсионные фонды; микрофинансовые организации; кредитные потребительские кооперативы; жилищные накопительные кооперативы; бюро кредитных историй; актуарии; кредитные рейтинговые агентства; сельскохозяйственные кредитные потребительские кооперативы; ломбарды.

Сектор, занимающийся финансовыми услугами, однако формально не входящий в финансовый сектор, считается «теневой» (параллельной) банковской системой. Крупнейшим подсектором теневой банковской системы выступают нерегулируемые инвестиционные фон- ды, который включают фонды денежного рынка и другие инвестиционные фонды (государственные и частные фонды). Вторым по размеру теневой системой является подсектор финансовых компаний. Из-за различий в законодательстве каждая юрисдикция самостоятельно определяет состав подсектора финансовых компаний. В частности, в Аргентине к ним относятся лизинговые и факторинговые компании, а также небанковские эмитенты кредитных карт, в Бразилии - лизинговые и микрофинансовые компании, компании ипотечного кредитования, небанковские эмитенты кредитных карт и т.д. В России среди крупнейших нерегулируемых финансовых рынков являются рынки лизинга и факторинга. [6]

Таким образом, опираясь на все наши рассуждения, рассматривая финансовую систему как финансовый сектор, происходит изучение структуры объекта, организация его элементов. Это не позволяет в полной мере соотнести категории «финансовая система» и «система финансовых институтов», так как система финансов институтов определяет не только институциональную структуру этих институтов, но и формирует отношения между ними.

Далее рассмотрим второй подход, раскрывающий содержание категории «финансовый институт», согласно которому под финансовым институтом следует понимать финансовые отношения.

При таком подходе понятия «система финансовых институтов региона» и «финансовая система» соотносятся совершенно иначе.

Среди российских экономистов, придерживающихся точки зрения, что финансовая система - это система отношений, следует выделить Кульчиеву М.Б., Лазарова Б.А, Вострикова Г.Г. и др.

Так, Кульчиева М.Б., Лазаров Б.А отмечают: «в мировом финансовом рынке предполагается присутствие финансовой системы - комплекса различных областей финансовых отношений, при реализации которых формируются и используются соответствующие денежные ресурсы» [7].

Востриков Г.Г. поддерживая эту мысль, пишет, что в структуру финансов как целостной категории с присущими ей общими свойствами входят несколько взаимосвязанных звеньев (институтов).

Финансовый институт - группа однородных 
экономических отношений, взаимосвязанных по формам и методам аккумуляции или распределения денежных средств.

Совокупность входящих в состав финансов Российской Федерации звеньев в их взаимосвязи образуют финансовую систему России. [8] Это широкий подход определения финансовой системы.

На наш взгляд, вполне логично отождествлять «совокупность входящих в состав финансов Российской Федерации звеньев в их взаимосвязи» с категорий «система финансовых институтов региона».

Используя подход, «финансовые институты финансовые отношения» финансовую систему региона следует определить как форму организации денежных отношений между институциональными единицами секторов экономики по поводу трансформации и распределения финансовых ресурсов.

В таком понимании система финансовых институтов региона не только структурирует финансовых посредников, а полностью образует финансовую систему целостным классифицированным набором финансовых институтов, организующих финансовую сферу и отношения между агентами по поводу аккумуляции, распределения и использования денежных средств.

При таком подходе, категории «система финансовых институтов региона» и «финансовая система» следует отождествлять.

Теперь рассмотрим институциональную структуру системы финансовых институтов региона:

1. Институты бюджетов и фондов:

- бюджетная система с входящими в нее государственными и местными бюджетами;

- внебюджетные целевые фонды;

- валютные резервы государства;

- финансы предприятий, объединений, организаций, учреждений, отраслей народного хозяйства

2. Институты - регуляторы (инфорсмент):

- Министерство финансов

- органы государственного управления РФ и субъектов Федерации (министерства, государ- ственные комитеты, департаменты и т.д.) в рамках отнесенных к их компетенции отраслей или сфер управления

- Центральный банк РФ

- Счетная палата РФ

- Федеральное казначейство

- Министерство РФ по налогам и сборам

- Государственный таможенный комитет и др.

3. Формальные институты:

- Конституция РФ

- Законы и нормативные акты по вопросам о финансах

4. Институты финансового посредничества:

- коммерческие банки (универсальные и специализированные),

- небанковские кредитно-финансовые институты (финансовые и страховые компании, пенсионные фонды, ломбарды, кредитные союзы и товарищества, организации микрофинансирования),

- инвестиционные институты (инвестиционные компании и фонды, финансовые брокеры, инвестиционные консультанты и пр.).

5. Институты, обеспечивающие функционирование финансовых рынков:

- фондовые биржи

- валютные биржи

Итак, подробно рассмотрев институциональную структуру системы финансовых институтов, можно сформулировать ее определение. Система финансовых институтов региона - это основополагающий элемент системы экономических институтов, институциональную структуру которой образует целостный набор финансовых институтов, организующих финансовую сферу и отношения между агентами по поводу аккумуляции, распределения и использования денежных средств в соответствии с принятыми правилами, регламентирующими поведение этих субъектов и упорядочивающими взаимодействие между ними в сфере финансовых отношений, и механизмами, обеспечивающими соблюдение данных правил.

\section{Библиографический список}

1. Колб Роберт В. Финансовые институт и рынки: учебник/ Роберт В. Колб, Рикардо Дж. Родригес, Пер.2-го амер. изд. Москва.2013. С. 315

2. Топсахалова, Ф.М-Г. Инвестиции: учебно-методическое пособие. 2016. С. 215

3. Востриков, Г.Г. Финансовое право. Saarbrücken. Germany: Palmarium Academic Publishing. 2012. С. 337 
4. Коваленко Ю.М. Институционализация финансового сектора экономики: монография / Коваленко Ю.М.НУДПСУ, 2013.- 608 с.

5. Monetary and Financial Statistics Manual and Compilation Guide. - IMF, 2016. - С. 33

6. Самиев П. Реформа лизингового сектора должна сделать его более доступным // Ведомости. 2017 . С.11

7. Кульчиева, М.Б., Лазаров, Б.А. Роль финансовых институтов в современном экономическом развитии // Международный журнал прикладных и фундаментальных исследований. 2015. № 6-3. С. 518-518

8. Востриков Г.Г. Финансовое право. Saarbrücken. Germany: Palmarium Academic Publishing. 2012. C. 337.

Поступила в редакцию 04.09.2018 